\title{
A Signaling Game Analysis of Project Investment on Equity Crowdfunding Platform
}

\author{
Man Li \\ School of Economics and Management, Beihang University, Beijing, China \\ Email: liman0205@buaa.edu.cn
}

How to cite this paper: Li, M. (2017) A Signaling Game Analysis of Project Investment on Equity Crowdfunding Platform. Open Journal of Social Sciences, 5, 276-283. https://doi.org/10.4236/jss.2017.53026

Received: March 6, 2017

Accepted: March 30, 2017

Published: April 6, 2017

\begin{abstract}
The development of equity crowdfunding has contributed to the growth of start-ups and raised a number of issues. The internet nature of the equity crowdfunding platform increases the information asymmetry between fundraisers and investors, leading to adverse selection, especially for individual investors with no investment experience. While the gradual rise of the domestic investment + following mode has expanded the negative impact of this problem. In this paper, the author proposes a signal transmission game model in which the business plan and the leader investors are used as reliable market signals, and both the project owners and the small investors are the game players. Then the author simulates the game process of both parties on the equity crowdfunding platform, and analyzes the hidden game theory, concluding that the key of the problem are fraud costs of problem projects and the cost gap between small investors following the lead investors and selecting projects by themselves. At last, the author provides some suggestions on how to reduce the adverse selection problem.
\end{abstract}

\section{Keywords}

Equity Crowdfunding, Information Asymmetry, Signaling Game

\section{Introduction}

Crowdfunding origins from crowdsourcing. It is a way of financing that entrepreneur release finance demand for supporting their project, accepting money from kinds of investors, giving them money or other substance as return simultaneously. [1] (Voorbraak) Recent years, crowdfunding platforms have developed quickly with the huge finance demanding of start-ups and the deep application of the Internet. Currently crowdfunding mainly include four type: reward crowdfunding, debts crowdfunding, donation crowdfunding and equity crowdfunding. Among them, the equity crowdfunding is the type studied in this paper. 
Equity crowdfunding refers to a way of finance that investors invest their money in the fundraiser's start-ups, getting a certain percentage of the shares, attaining income when the companies go to public or are bought by other companies. [2] (Dong Yang, 2014) Equity crowdfunding is the most promising to help start-up business growth among the four types of crowdfunding. Otherwise, generally equity crowdfunding involved in the more amount of money, more vulnerable to the legal red line, which attracted the attention of investors and academics enough.

As we all know, in the traditional VC, there is information asymmetry between venture capital firms and start-ups, thus producing adverse selection. And it is more likely to exist on equity platform than general VC because all these works like the selection of projects or trade happen on the internet, and the network hinders the flow of information. That is to say, for most investors on the equity platform especially the small investors lacking experience of investing, it is very difficult to get access to the real information of the quality of teams and projects. Then the information asymmetry happens. And under the model of leading-invest and following-invest that lots of platforms have adopted, the effect of sheep flock may amplify the consequences of this problem. This paper proposes to applicate a signal transfer game model, regarding business plan books and investment leaders as reliable market signals, to simulate the process of signal transmission between investors and funders on the platform. Then the author makes some suggestions for avoiding the problem of adverse selection.

\section{Introduction to Previous Research and Signal Game Theory}

\subsection{Introduction to Previous Research}

The research on the signals in the past is focused on the influence of the signal information of the project starters on the funding success. Gerrit K.C. Ahlers (2015) studied the signals of the start-ups which influence whether the small investors give money to them, mainly focusing on four aspects of the signals: firms' financial roadmaps, external certification, internal governance, risk factors. Their data highlight the importance of financial roadmaps and risk factors, as well as internal governance. External certification has little or no impact on success. [3] A Koutun (2016) divide the signals that affect funding success into finance signals (funding goal and price per share) and quality signals (external certification and internal governance). The finance signals have negative effects on funding success while the quality signals have positive effects. [4] There is no shortage of domestic research on such issues. For instance, Haichao Zheng (2015) [5] and Lin Chen [6] (2016) have explored the factors that affect the financing results through the empirical or the establishment of the model. These studies are all very instructive for start-up companies to obtain investor investment. The project leader can choose a better way to show his/her quality signal to investors according to predecessors. However, it is the huge amount of investors who bear the greatest risk, especially the inexperienced small investors who need to give 
money and take risks. Besides, they may also take the risk that the investing leaders collude with entrepreneurs, and the start-ups themselves might cheat and run away with the money. Therefore, during the process of equity crowdfunding, reducing the information asymmetry and adverse selection is the key to lower the small investors' risks.

There are also researchers who choose to use the information transfer game model to study the problem of information asymmetry. For example, Bing $\mathrm{Lu}(2016)$ select the award crowdfunding for the research object, aiming at the problem of information asymmetry between the fundraisers and the crowdfunding platform, a signal game model is established, and three Bayesian equalizations are analyzed in depth to provide a strategy for platform development. [7] Junhui Xu (2015) argued that information asymmetry will interfere investors to interpret the platform and project information, so that make it difficult to distinguish the merits or defects of the project. Only if the excellent teams transfer their own advantage information through the business plan effectively to investors will they obtain the recognition of investors. [8] However, the researchers are few, and there is no focus on the most important model-equity crowdfunding in the research, so this paper is trying to make up for this loophole. In this paper, from the perspective of investors selecting the project, the author simulates the game behavior of the funders and investors in the financing process of the equity crowdfunding platform, analyzing the factors that lead to the adverse selection, and then make the reasonable suggestion.

\subsection{The Application of Signal Transfer Game Theory in This Paper}

For general project evaluation, we usually use methods like cash flow, net present value, internal income (IRR), etc. While the object of what are invested on the equity crowdfunding platform are always some brand new start-ups where there is so much uncertainty in the aspect of technology, market, finance and management. So it's hard to make estimation of cash flow in the future, the promise of the sale and market competitors; besides, there is a serious information asymmetry between the project starter and the investor. That is to say, the process of selecting the equity crowdfunding projects is actually a process of investors making an uncertainty decision. So the author believes that game theory analysis of the information economics can be used in the process of selecting an equity projects. The signal transfer model was proposed by Michael Spence [9] in 1973 to solve the problem of adverse selection caused by information asymmetry. In the classic Spence job market model, Harvard MBA chose the educational background as a signal to enter the workplace, where they make distinction with the lower education people. This paper envisages finding such a signal in equity investment projects to solve the problem of adverse selection in the equity crowdfunding.

There are many crowdfunding platforms, and the operation process and model of each platform are slightly different, but there is no big difference. As follows: 


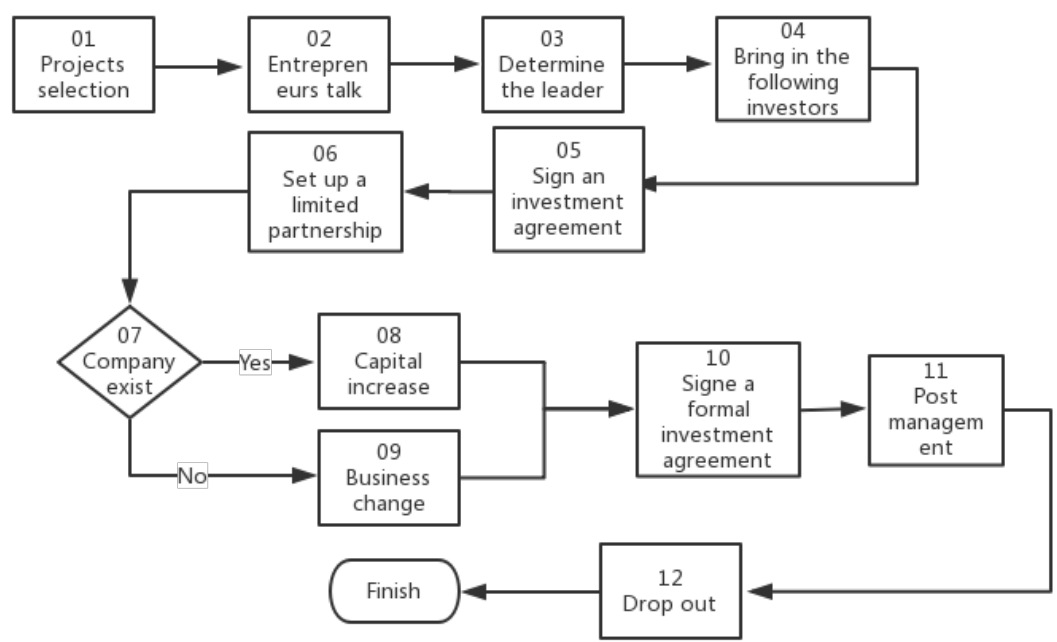

In the process of project selection, the platforms first check the project business plan to determine whether the project can be on-line. And then the platform should also have a due diligence link, that is investigating the project from the finance to the operation in depth. But there are few platforms doing this, that is to say, a large number of projects of uneven quality are exposed to the inexperience individual investors on the equity crowdfunding platform. Investors select the entrepreneurs worth interviewing through the screening of business plans and other information, or follow experienced investment leaders or institutions. So the business plan is good or bad and the investment leader directly determines the individual investors' capital flows. Investors' insight into the signals that the business plan and the leaders transfer also directly determine the success or failure of the investment. Therefore, the author believe that business plans and investment leaders can be used as an effective signal to convey the quality of the project to investors, that is, investors can screen out a high level of business plan to reduce the possibility of adverse selection.

\section{Signal Transfer Game Analysis of Project Selection of Equity Crowdfunding}

\subsection{The Basic Assumptions of the Model}

(1) The game exists where the environment is a mixed equity crowdfunding market including leading + following investment mode and other models. The participants in the game is the owners of the project and individual investors, both of which are rational economic people, viewing pursuing their own profit maximization as the goal, and are risk of rendering. Assume that the individual investors invest in the enterprise as A and agree that when the project is successful, the project owner and the leader receive the profit of $\mathrm{m} \%$, and the individual investor earns $(1-\mathrm{m}) \%$ profit.

(2) There are a large number of individuals who do not have rich investment experience, called individual investors. Because the investment experience is limited, assume that when they do not follow the investment leaders, the probability of they selecting problem projects is $90 \%$, the probability of picking a good 
project is $10 \%$.The investment leaders include the justice leaders and the injustice leaders. The justice leaders will pick the good projects and convene with the following investors, the injustice leaders collude with project funders, using herding effect to cheat individual investors. Suppose justice and injustice leaders accounted for $90 \%$ and $10 \%$ respectively. And assume that the investment leaders have the ability to pick out a good project, that is, the probability of justice leaders selecting problem projects is 0 .The probabilities of individual investors choosing to follow the investment leaders and not follow area and $\mathrm{b}$ respective$\operatorname{ly}(a+b<1$, and $\lim (a-b) \neq 0)$.

(3) Because the exit mechanism of the current equity crowdfunding is not perfect, there is no sound legal protection, so assume that once the projects fail, or small investors invest the projects where the leader and the project collude, the individual investors will lose all the investment. A good project upload real business plans to the platform, including real business models, financial plans, management team capabilities, etc. And the problem project will make fake business plans for obtaining funds, set fake cost as $C_{1}$.

(4) Set the actual profitability of the good projects as $R_{1}$, the actual profitability of the problem project as $R_{2}$. Obviously, $R_{1}>0, R_{2}<0$, that is good project profit, and problem items loss.

(5) If the individual investors choose to follow, they must pay the leader the additional commission. When choosing a project by themselves, they may also spend time and money. So set the cost of following investment as $C_{2}$, the cost of their own choice for the project as $C_{3}$.

\subsection{The Process of the Game}

(1) First of all, the projects on the equity crowdfunding platform are divided into good projects and problem projects.

(2) Then individual investors take action to invest in the entire market.

(3) Investors' investment has five results: following, invest in a good project led by just leaders; following, invest in a project where project fundraisers collude with unjust leader; not with leaders, invest in good projects; Not following the leaders, invest the problem project; not make an investment.

The participant's game process is as follows:

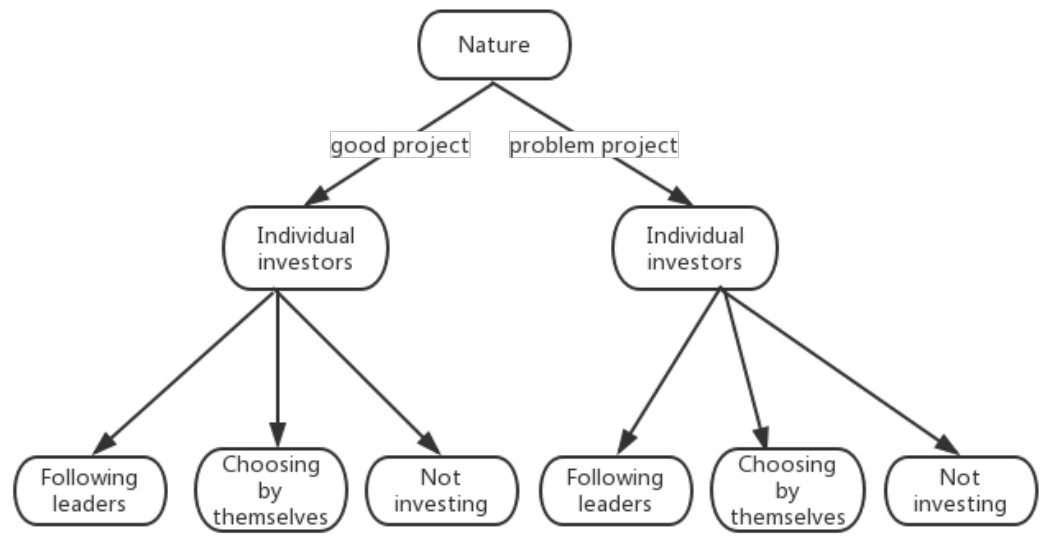




\subsection{Analysis and Conclusion of Game}

According to this model, we can calculate the expected return of different projects owners and the investors take different actions.

1) Expected return of good project business is:

$$
E_{1}=A * R_{1} * m * a+A * R_{1} * m * b=A * R_{1} * m *(a+b)
$$

2) Expected return of problem project business is:

$$
E_{1}=-C_{1} *(1-a-b)+\left[A *\left(1+R_{2}\right)-C_{1}\right] *(a+b)=A *\left(1+R_{2}\right) *(a+b)-C_{1}
$$

3) Expected return of individual investors who follow leaders:

$$
\begin{aligned}
& E_{3}=\left[A * R_{1} *(1-m)-C_{2}\right] * 90 \% * a+\left(-C_{2}-A\right) * 10 \% * a \\
& =A * R_{1} *(1-m) * 90 \% * a-A * a * 10 \%-C_{2} * a
\end{aligned}
$$

4) Expected return of individual investors who invest projects by themselves:

$$
\begin{aligned}
& E_{4}=\left[A * R_{1} *(1-m)-C_{3}\right] * 10 \% * b+\left(-A-C_{3}\right) * 90 \% * b \\
& =A * R_{1} *(1-m) * b * 10 \%-A * b * 90 \%-C_{3} * b
\end{aligned}
$$

From above, conclusions can be drawn as follows:

a) The condition that the problem projects do not apply for being on the platform: $E_{2}<0$, that is $A *\left(1+R_{2}\right) *(a+b)-C_{1} \leq 0$, that is $C_{1} \geq A *\left(1+R_{2}\right) *(a+b)$.

Conclusion 1: If the cost of the project is large to a certain extent, the enterprise will not make fake business plan to cheat investors.

We can find something from the above inequality: the larger $C_{1}$, the small $R_{2}$, that is, the greater the cost of fundraisers forging, the lower the rate of return, the larger the possibility that project owners do not apply to be on the platform.

b) The condition of Individual investors choosing to following the leader is:

$$
\begin{aligned}
& E_{3} \geq E_{4}, \text { that is } \begin{array}{r}
A * R_{1} *(1-m) * 90 \% * a-A * a * 10 \%-C_{2} * a \\
\geq A * R_{1} *(1-m) * b * 10 \%-A * b * 90 \%-C_{3} * b
\end{array} \text {, that is } \\
& a * C_{2}-b * C_{3} \leq k \quad(\mathrm{k} \text { is a constant) }
\end{aligned}
$$

Conclusion 2: For Individual investors, only if the cost of following leaders is smaller than the cost of their own selection of a project to a certain extent, they will choose to invest a project following investment leaders rather than selecting a project by themselves.

\section{Suggestions for Reducing the Adverse Selection on Equity Crowdfunding Platform}

According to conclusion 1, in order to reduce the loss of small investors caused by adverse selection, we must first increase the cost of forging a crowdfunding project. For example, the platform can require the business plan of the project to attach the certificate of the patent, the detailed credit information of the project leader, or the project credit certificate issued by the authoritative credit rating agency. For those who want to cheat for investment, the cost of obtaining these certificates is high, and it is considered whether the fraud is cost-effective. Oth- 
erwise, it is very difficult to achieve such a rigorous system. First of all, the platform is based on profitability, the more the projects through the platform audit, the more likely platform profits, so the platforms have motivation to relax the audit of the project. This requires our regulators to monitor the crowdfunding platform strictly, to push the platform develop more stringent auditing policy for projects. Second, China's personal credit system is not yet perfect, it is difficult to obtain the project leader's credit history. Therefore, we have to establish and improve the personal credit system. For the small enterprises on the crowdfunding platform, it is significant to improve the accountant, lawyer system, which can better ensure the enterprise's financial audit and credit proof.

Then, the crowdfunding platform should focus on protecting the interests of small and medium investors, to reduce the cost of they investing projects led. The public platform should not only develop strict application requirements, but also increase the protection of small investors to better guide their investment in the platform. On the one hand, they can limit the highest standards of the commission that the small investors are claimed by leaders. On the other hand, the layout of the page should be more clear, using scientific way to sort the project, to avoid the problem items occupying a large headline.

Afterwards, individual investors improve their ability to identify projects. As an investor, they should improve their ability to identify the project to reduce their losses. It is not recommended that novice investors invest on the crowdfunding platform in order to obtain the interests, because the projects on the internet are quite mixed, and the current security system is not perfect. It is easy to cause losses. And the platform should also improve the access mechanism for investors to reduce the unnecessary losses of them. In addition, the platform needs to improve the leadership + following mechanism, to avoid collusion of the leader and the project owner which might result in herding effect.

\section{Lack and Prospect}

The purpose of this paper is to point out that the information asymmetry in the crowdfunding market leading to the problem of adverse selection, and put forward some suggestions through the analysis. The process of analysis may be partial, because the basic assumptions in reality is impossible to set up. In addition, business plans can be used as the main signal of the project, but there are many other factors cannot be ignored, such as the project owner's qualifications and credit. Projects and people are actually important equally, and this article only discussed the project and investment leaders, so the author hope follow-up researchers to add.

Equity crowdfunding face all the Internet people, helping start-up companies quickly get money to develop their own business, which is our very needed model. But its rapid development has brought a lot of trouble, such as the information asymmetry mentioned in this article causing a series of problems and a lot of collapse of the crowdfunding platform. Coupled with imperfect laws and regulations, the interests of a large number of investors cannot be guaranteed. 
So, for this aspect of the study we have a long way to go. The after scholars can pay more attention to the development of laws and regulations, platform supervision, the evaluation of various projects.

\section{References}

[1] Voorbraak, K.J.M. (2011) Crowdfunding for Financing New Ventures: Consequences of the Financial Model on Operational Decisions. Eindhoven University of Technology, Eindhoven.

[2] Yang, D. (2014) The Operation Mode and Risk Prevention of the Equity Crowdfunding. Journal of the National Academy of Public Security, 22,157-168.

[3] Ahlers, G.K.C., Douglas, C., Christina, G. and Denis, S. (2015) Signaling in Equity Crowdfunding. Social Science Electronic Publishing, 39, 955-980.

[4] Koutun, A. Quality Signals in Equity-Based Crowdfunding.

[5] Zheng, H.C., Huang, Y.M., Wang, T. and Chen, D.Y. (2015) A Study on the Influencing Factors of Innovative Projects' Equity Crowdfunding. Chinese Soft Science, $1,130-138$.

[6] Chen, L. and Yu, M.Y. (2016) An Empirical Study on the Factors Affecting the Performance of Equity Financing. Journal of Shandong Agricultural University (Natural Science Edition), 47, 623-627.

[7] Lu, B. and Shi, K.R. (2016) Signal Game Analysis on the Development Strategy of Crowdfunding Platform Under Information Asymmetry. Enterprise Economy, 6, 49-53.

[8] Xu, J.H. (2015) Effective Docking of Crowdfunding and Cooperative Investors: Research on Signal Transmission Model. Financial Theory and Practice, 11, 8-13.

[9] Spence, M. (1973) Job Market Signaling. Quarterly Journal of Economics, 87, 355374. https://doi.org/10.2307/1882010

\section{Scientific Research Publishing}

\section{Submit or recommend next manuscript to SCIRP and we will provide best} service for you:

Accepting pre-submission inquiries through Email, Facebook, LinkedIn, Twitter, etc. A wide selection of journals (inclusive of 9 subjects, more than 200 journals)

Providing 24-hour high-quality service

User-friendly online submission system

Fair and swift peer-review system

Efficient typesetting and proofreading procedure

Display of the result of downloads and visits, as well as the number of cited articles

Maximum dissemination of your research work

Submit your manuscript at: http://papersubmission.scirp.org/

Or contact jss@scirp.org 